\title{
Horizontal Pendulum Performance Analysis with Multilevel Model Plate on Ocean Wave Electric Power Plant (PLTGL)
}

\author{
Mukhtasor $^{1}$, Tony Bambang Musriyadi ${ }^{2}$, Irfan Syarief Arief ${ }^{3}$, Ardika Wendy Cahya Saputra ${ }^{4}$
}

\begin{abstract}
It encourages all parties to be more advanced and developed by creating solutions to renewable energy generation with the latest innovations, one of which is the sea wave power plant - pendulum system. Pontoon which uses pendulum system is one tool used to convert from ocean wave energy into electrical energy. In this study, the test conditions without using ballast onshore and off-shore testing with the ballasts. Obtained from testing the many rounds that can be generated pendulum pie plate thickness and the angle of the pontoon. To test the largest on-shore power obtained on the test using arc angle $30^{\circ}, 3 \mathrm{~mm}$ thick, the angle of $60^{\circ}$ power produced 0036 watts. For testing offshore in the ballasts $12 \mathrm{~cm}, 15 \mathrm{~cm}, 17.5 \mathrm{~cm}$, the largest power generated at $15 \mathrm{~cm}$ ballasts with 0041 watts power on pie, thick, and a tilt angle equal to the on-shore testing. Number of rounds with time, the on-shore testing that produces the greatest value in the segment with an angle of $30^{\circ}$, a thickness of $3 \mathrm{~mm}$ the angle of $60 \mathrm{o}$ value obtained $0.938 \mathrm{rad} / \mathrm{s}$. In the off-shore test is highest value is filled with $15 \mathrm{~cm}$ ballasts with $0847 \mathrm{rad} / \mathrm{s}$.
\end{abstract}

Keywords - pontoon, pendulum system, test the on-shore, off-shore test, power

\section{INTRODUCTION}

$\mathrm{W}$ ith population growth and increasing technological development and the resulting human increasingly dependent on fossil energy sources that can not be updated. Energy sources such as petroleum, natural gas and coal are expected to run out about the next 30 years. This causes the energy crisis in the world and make human thought to find the most energy that does not depend on fossil fuels today. In addition dwindling fossil energy and require a long time to produce this energy back, and can damage the environment due to gas emissions and other pollution caused. The use of nuclear energy requires a high cost as well as limited security issues.

Hydropower generation not applicable in many places because of the availability of water.

It is necessary to search for the source of environmental friendly energy and renewable. Solar, wind, sea, water, electromagnetic, electrostatic, thermal, vibration, and movement of the human body are all kinds of renewable energy sources [1].

In this analysis, the problem of the subject in the preparation of this study are:

1) What is the greatest power generated by each of the differences, thick, and the slope angle of the pontoon to the generated power?

2) What is the use of arc with a certain thickness to obtain the number of rounds and the most optimal time?

3) What is the use of ballasts, to obtain the greatest power and the number of revolutions with a specific time greatest? While the purpose of this study was to answer the question above.

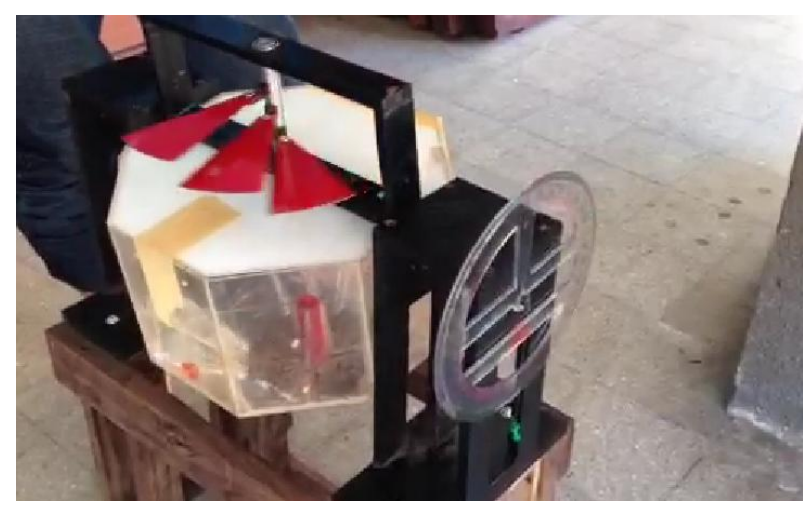

Figure. 1.On-shore test

Mukhtasor, Department of Ocean Engineering, Institut Teknologi Sepuluh Nopember, Surabaya 60111, Indonesia. Email:-

Tony Bambang Musriyadi, Department of Marine Engineering, Institut Teknologi Sepuluh Nopember, Surabaya 60111, Indonesia. Email:-

Irfan Syarief Arief Department of Marine Engineering, Institut Teknologi Sepuluh Nopember, Surabaya 60111, Indonesia. Email:irfansya@its.ac.id

Ardika Wendy Cahya Saputra, Surabaya 60111, Indonesia. Email:-

\section{METHOD}

The methodology to be used in completing this research is through modeling approaches with 1:10 scale from actual size. Then it will be tested. 
TABLE 1.

TABLE EXPERIMENTAL RESULTS 1MM THICKNESS

\begin{tabular}{|c|c|c|c|c|}
\hline \multirow[b]{2}{*}{ No. } & \multirow[b]{2}{*}{ Pendulum Angle } & \multirow[b]{2}{*}{ Time } & \multicolumn{2}{|c|}{ Total Rotation } \\
\hline & & & Clock Wise & $\begin{array}{c}\text { AntiClock } \\
\text { Wise }\end{array}$ \\
\hline 1 & $5^{\circ}$ & 0 & 0 & 0 \\
\hline 2 & $15^{\circ}$ & 0 & 0 & 0 \\
\hline 3 & $30^{\circ}$ & 4,61 & 2 & 1 \\
\hline 4 & $45^{\circ}$ & 7,52 & 2 & 2 \\
\hline 5 & $60^{\circ}$ & 9,55 & 3 & 2 \\
\hline
\end{tabular}

\section{EXPERIMENT AND SIMULLATION RESULTS}

\section{A. Onshore Test}

The test is conducted by assembling a pontoon which there is a segment with a $30^{\circ}$ angle, with each - each a thickness of $1 \mathrm{~mm}, 2 \mathrm{~mm}, 3 \mathrm{~mm}$. then with a buffer as shown in the picture 3.1 , will be tilted at an angle $5^{\circ}, 15^{\circ}$, $30^{\circ}, 45^{\circ}, 60^{\circ}$.

This experiment will be known from the number of revolutions during the time stops. Table 3.1 shows the experimental results on a pontoon using a pie with a certain angle.

\section{B. Offshore Test}

Testing of off-shore is a test in the water or in the pool using ballasts with a depth of $12 \mathrm{~cm}, 15 \mathrm{~cm}, 17.5$ $\mathrm{cm}$ measured on the one part thereto, as shown in the Figure 2. Tests on ballasts system is almost the same as on-shore testing only place using water medium. The experimental results are shown by Table 2. It uses ballasts $12 \mathrm{~cm}, 15 \mathrm{~cm}, 17.5 \mathrm{~cm}$ with a thickness of $1 \mathrm{~mm}$.

Pontoon filled with ballasts $12 \mathrm{~cm}, 15 \mathrm{~cm}, 17.5 \mathrm{~cm}$, then given a pendulum with a $30^{\circ}$ angle with a thickness of $1 \mathrm{~mm}, 2 \mathrm{~mm}, 3 \mathrm{~mm}$. After that the new pontoon tilted with a slope of $5^{\circ}, 15^{\circ}, 30^{\circ}, 45^{\circ}, 60^{\circ}$

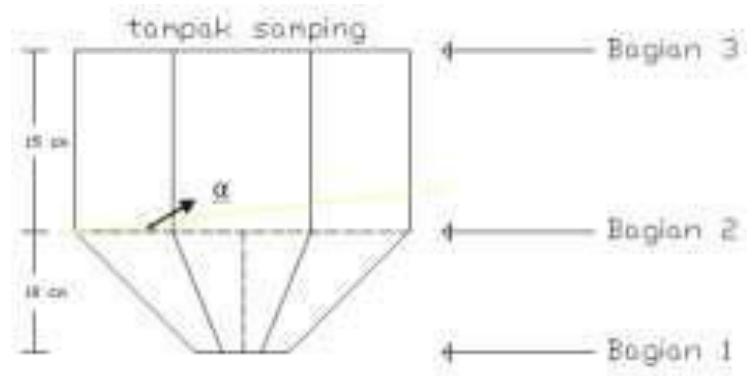

Figure. 2. Pontoon with a depth of each ballast

TABLE 2.

THE RESULTS OF THE EXPERIMENT 1MM THICKNESS, 12 CM BALLAST

\begin{tabular}{ccccc}
\hline \multirow{2}{*}{ No. } & Pendulum Angle & Time & \multicolumn{2}{c}{ Total Rotation } \\
\cline { 4 - 5 } & & & Clock Wise & AntiClock Wise \\
\hline 1 & $5^{\circ}$ & 0 & 0 & 0 \\
\hline 2 & $15^{\circ}$ & 0 & 0 & 0 \\
\hline 3 & $30^{\circ}$ & 4,61 & 1 & 1 \\
\hline 4 & $45^{\circ}$ & 7,52 & 2 & 1 \\
\hline 5 & $60^{\circ}$ & 9,55 & 2 & 2 \\
\hline
\end{tabular}

TABLE 3.

THE RESULTS OF THE EXPERIMENT 1MM THICKNESS, 15 CM BALLAST

\begin{tabular}{|c|c|c|c|c|}
\hline \multirow[b]{2}{*}{ No. } & \multirow[b]{2}{*}{ Pendulum Angle } & \multirow[b]{2}{*}{ Time } & \multicolumn{2}{|c|}{ Total Rotation } \\
\hline & & & Clock Wise & $\begin{array}{l}\text { AntiClock } \\
\text { Wise }\end{array}$ \\
\hline 1 & $5^{\circ}$ & 0 & 0 & 0 \\
\hline 2 & $15^{\circ}$ & 2,02 & 1 & 0 \\
\hline 3 & $30^{\circ}$ & 4,24 & 2 & 1 \\
\hline 4 & $45^{\circ}$ & 6,86 & 3 & 2 \\
\hline 5 & $60^{\circ}$ & 8,76 & 3 & 3 \\
\hline
\end{tabular}


THE RESULTS OF THE EXPERIMENT 1MM THICKNESS, 17,5 CM BALLAST

\begin{tabular}{ccccc}
\hline & & & \multicolumn{2}{c}{ Total Rotation } \\
\cline { 3 - 5 } No. & $\begin{array}{c}\text { Pendulum } \\
\text { Angle }\end{array}$ & Time & $\begin{array}{c}\text { Clock } \\
\text { Wise }\end{array}$ & $\begin{array}{c}\text { AntiClock } \\
\text { Wise }\end{array}$ \\
\hline 1 & $5^{\circ}$ & 0 & 0 & 0 \\
\hline 2 & $15^{\circ}$ & 2,02 & 1 & 0 \\
\hline 3 & $30^{\circ}$ & 3,32 & 1 & 1 \\
\hline 4 & $45^{\circ}$ & 6,03 & 2 & 1 \\
\hline 5 & $60^{\circ}$ & 7,98 & 2 & 2 \\
\hline
\end{tabular}

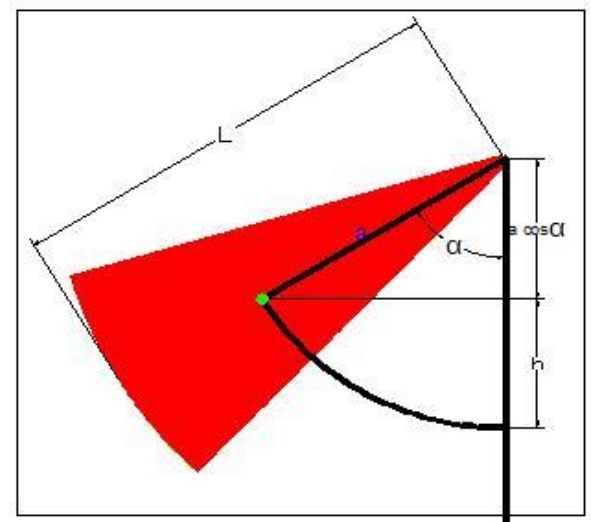

Figure. 3. The scheme of the arc

In the off-shore testing will be performed calculations to determine the power generated at each arc with a certain thickness.

High-arc

Long emphasis

(L) $=11.5 \mathrm{~cm}=0.115 \mathrm{~m}$

arc slope angle

(a) $=7246 \mathrm{~cm}=0.07246 \mathrm{~m}$

$(\alpha)=60^{\circ}$

The density of iron $(\rho)=7800 \mathrm{~kg} / \mathrm{m}^{3}$

Plate thickness $\quad=1 \mathrm{~mm}=0.001 \mathrm{~m}$

for heavy arc on arc angle $30^{\circ}$ with $1 \mathrm{~mm}$ thick

with a slope of $60^{\circ}$.

Wide arc $=30^{\circ} / 360^{\circ} \mathrm{x}$ wide circle

$$
=30^{\circ} / 36^{\circ} \times 3.14 \times 0.115 \times 0.115
$$$$
=0.00346 \mathrm{~m} 2
$$

Volume $=$ Area $\mathrm{x}$ pie plate

$$
=0.00346 \mathrm{~m} 2 \times 0.001 \mathrm{~m}
$$

$$
=0.00000346 \mathrm{~m} 3
$$

Mass arc $\rho=x$ Volume

$$
\begin{aligned}
& =7800 \mathrm{~kg} / \mathrm{m} 3 \mathrm{~m} 3 \times 0.00000346 \\
= & 0.027161 \mathrm{~kg}
\end{aligned}
$$

$\mathrm{G}=27,161$

Furthermore, for torque and power

Before seeking the value, to determine a (long-emphasis) using software SolidWork. Then the value of longgravity $0.0724 \mathrm{~m}$.

The value of $\mathrm{h}=\mathrm{a}-\mathrm{a} \cos \alpha$

$$
\begin{aligned}
& =0.07246-0.07246 \cos 60 \\
& =0.036 \mathrm{~m}
\end{aligned}
$$

By using the same software, the inertia value of $274.71 \mathrm{gcm}^{2}=0.027471 \mathrm{gm}^{2}$. The following data processing on -shore in theory and practice by using a segment with a $30^{\circ}$ angle with a thickness of $1 \mathrm{~mm}$ with a slope of $60^{\circ}$ arc.
Furthermore, to determine the value of the torque and power, need to know the results of the omega $(\omega)$. Value omega $(\omega)$ calculated by the following formula:

$(\omega)=\sqrt{\frac{2 m g h}{I}}$

Mass arc $(\mathrm{m})$

$\mathrm{h}(\mathrm{a}-\mathrm{acos} a)$

$=9.8 \mathrm{~m} / \mathrm{s} 2$

$\mathrm{h}(\mathrm{a}-\mathrm{a} \cos \alpha)$

$=0.036 \mathrm{~m}$

Moment of Inertia ( I )

$=0,027471 \mathrm{gm}^{2}$

$\omega=\sqrt{\frac{2 \times 27.161 \times 9.8 \times 0.36}{0.027471}}$

$\omega=26.41 \mathrm{rad} / \mathrm{s}$

$$
\begin{aligned}
\text { Torque }(\mathrm{T}) & =\mathrm{mg} \sin 60 \mathrm{a} \\
& =27,161 \times 9,8 \times \sin 60 \times 0,07246 \\
& =27,161 \times 9,8 \times 0,866 \times 0,07246 \\
& =16,7 \mathrm{gm} 2 / \mathrm{s} 2 \\
& =16,7 \times 10-3 \mathrm{Nm} \\
\text { Daya } \quad & \mathrm{T} \times \omega \\
= & 16,7 \times 10-3 \times 26,41 \\
= & 0,441 \text { Watt }
\end{aligned}
$$

Then the results obtained by using the theory of the power of 0441 Watts.

Next calculate the power by using calculation practicum.

omega $(\omega) \quad=\Sigma$ rotation $/$ time

$$
\begin{aligned}
& =5 / 9.55 \\
& =0.5234 \mathrm{rad} / \mathrm{s}
\end{aligned}
$$

So, Torque $(\mathrm{T})=m g \sin 60 \mathrm{a}$

$$
\begin{aligned}
& =27.161 \times 9.8 \times \sin 60 \times 0.0726 \\
& =27.161 \times 9.8 \times 0.866 \times 0.0726 \\
& =16.7 \mathrm{gm}^{2} / \mathrm{s}^{2} \\
& =16.7 \times 10^{-3} \mathrm{Nm}
\end{aligned}
$$


TABLE 5.

THE CALCULATION FORMULA

\begin{tabular}{|c|c|c|c|c|c|c|c|c|c|}
\hline \multirow{2}{*}{ Angle Arc } & \multirow{2}{*}{ Thick ness } & \multirow{2}{*}{ Mass (Kg) } & \multirow{2}{*}{ Volume $\left(\mathrm{m}^{3}\right)$} & \multirow{2}{*}{$\mathrm{I}\left(\mathrm{Kgm}^{2}\right)$} & \multicolumn{5}{|c|}{$\mathrm{h}(\mathrm{m})$} \\
\hline & & & & & 5 & 15 & 30 & 45 & 60 \\
\hline \multirow{3}{*}{$30^{\circ}$} & 1 & 0,027 & 0,0000034 & 0,000034 & \multirow{3}{*}{0.000290} & \multirow{3}{*}{0.002534} & \multirow{3}{*}{0.0097016} & \multirow{3}{*}{0.021213} & \multirow{3}{*}{0.0362} \\
\hline & 2 & 0,054 & 0,0000069 & 0,000067 & & & & & \\
\hline & 3 & 0,081 & 0,0000104 & 0,000101 & & & & & \\
\hline
\end{tabular}

Power

$$
\begin{aligned}
& =\mathrm{T} \times \omega \\
& =16.7 \times 10^{-3} \times 0.5234 \\
& =8.74 \times 10^{-3} \text { Watt }
\end{aligned}
$$

Results southwest practices is $8.74 \times 10-3$ Watt. In accordance with the above formula, the obtained

Furthermore, after the above table to calculate the value of omega, torque, power. Calculations can be done on each test.

Data from the table above will be analyzed using next graph. For data on-shore will be analyzed with a difference theory with practical work and the influence of thickness on each plate of the power generated, and the number of revolutions of the pendulum with a stop at a certain slopes.

\section{ANALYSIS AND DISCUSSION}

\section{A. Offshore Test}

Here's one example, Data Analysis shown in the analysis of the on-shore testing theoretical and practical calculations.

In this graph shows that the theoretical value is greater than the lab. $30^{\circ}$ angle thick one, with slope of $5^{\circ}$ is 0004 watts, the power generated by the lab 0 watts. Then at the angle of $15^{\circ}$ theoretically generated power 0035 watt in lab 0 watts. At the angle of 300 power theoretically produced 0132 watts of power generated in the lab 0006 watts. The tilt angle of $45^{\circ}$ is theoretically generated power 0277 watt, 0007 watt in the lab. At the angle of the theoretical power of 600 watts in a practicum 04430009 watts.

In theory and practice produce nearly the same graph, where the greater the tilt angle, the greater the power generated. Likewise happens in each arc that has a certain thickness, the shape of the graph obtained relatively the same,

Then in graph theory and practicum one example on the graph below, the arc angle $30^{\circ}$ with a thickness of $1 \mathrm{~mm}$.

TABLE 6.

THE CALCULATION ARC $30^{\circ} 1 \mathrm{MM}$ THICK

\begin{tabular}{ccccccc}
\hline $\begin{array}{c}\text { Angle } \\
\text { Arc }\end{array}$ & $\begin{array}{c}\omega \text { Theory } \\
(\mathrm{rad} / \mathrm{s})\end{array}$ & $\begin{array}{c}\omega \text { Practice } \\
(\mathrm{rad} / \mathrm{s})\end{array}$ & $\begin{array}{c}\text { T Theory } \\
(\mathrm{Nm})\end{array}$ & $\begin{array}{c}\text { T Practice } \\
(\mathrm{Nm})\end{array}$ & $\begin{array}{c}\text { Power } \\
\text { Theory } \\
(\text { Watt }\end{array}$ & $\begin{array}{c}\text { Power } \\
\text { Practice } \\
\text { (Watt) }\end{array}$ \\
\hline 5 & 2.313 & 0 & 0.002 & 0.002 & 0.004 & 0 \\
\hline 15 & 6.920 & 0 & 0.005 & 0005 & 0.035 & 0 \\
\hline 30 & 13.717 & 0.487 & 0.010 & 0010 & 0.132 & 0.005 \\
\hline 45 & 20.280 & 0.444 & 0.014 & 0.014 & 0.277 & 0.006 \\
\hline 60 & 26.496 & 0.480 & 0.017 & 0.017 & 0.443 & 0.008 \\
\hline
\end{tabular}

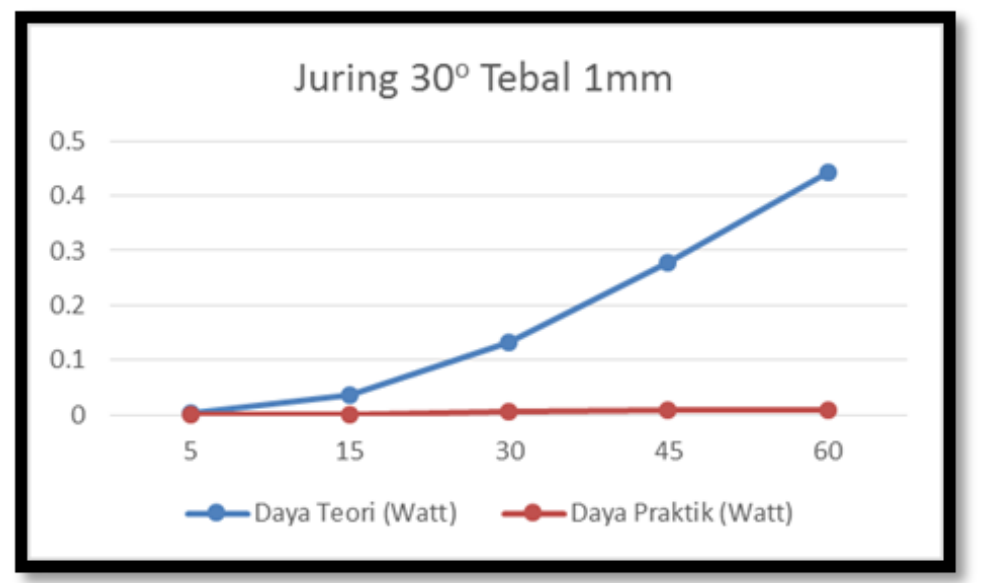

Figure. 4. Ratio of power in theory with practical results in the power arc with a $30^{\circ}$ angle $1 \mathrm{~mm}$ thick 


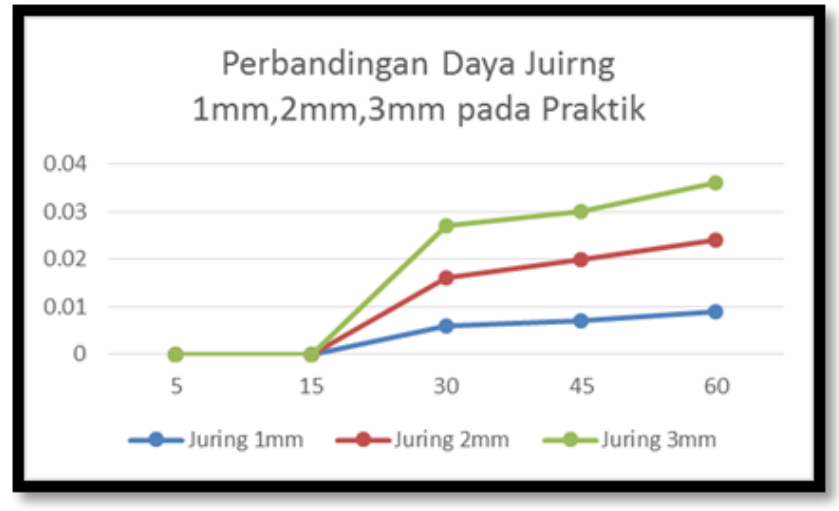

Figure. 5. comparison of the lab on top of the angle of $30^{\circ}$ thickness of $1 \mathrm{~mm}, 2 \mathrm{~mm}, 3 \mathrm{~mm}$

From here it can be seen that the theoretical and practical work together to increase in the angle of the greater power even though the difference between practical and theoretical approximately less than $20 \%$. This is because the error readings, and bearings that are used during the test was also very influential.

\section{B. Onshore Test}

Analysis of On-shore in the lab, the arc with the $300,1 \mathrm{~mm}$ thick, $2 \mathrm{~mm}, 3 \mathrm{~mm}$.

In this lab arc with $1 \mathrm{~mm}$ thick, the angle of 300 , has a value of omega most big that $0.651 \mathrm{rad} / \mathrm{s}$ in which the number of rotation 3 times the time it takes $4.61 \mathrm{~s}$. With a thickness of $2 \mathrm{~mm}$, tilt angle 300memiliki omega greatest value is $0839 \mathrm{rad} / \mathrm{s}$ in which the number of revolutions produced 4 times within 4.77 s. In the arc with a thickness of $3 \mathrm{~mm}$, the angle of 300 , has a value of omega $0938 \mathrm{rad} / \mathrm{s}$. Then the most lucrative time rotation compared with the largest is the arc at an angle of 600 , at an angle of 300 with a thickness of $3 \mathrm{~mm}$ number of rounds produced 5 times and the time it took $5: 33 \mathrm{~s}, 0938 \mathrm{rad} / \mathrm{s}$

In the graph above shows that omega generated not depending on the thickness and the angle of inclination, this is because at trial the greater the angle of this case could lead to a pendulum that works more quickly stopped because of the influence of the waves.

\section{CONCLUSION}

Based on the discussion in the previous chapter, can be summarized as follows:

1. Calculations using the theory was found that the greater the weight of the pendulum or the pendulum angle and the thickness of the power generated will be even greater.

2. In the On-shore testing arc angle of 300, the largest power produced at a thickness of $3 \mathrm{~mm}$ at an angle of 600 , the generated power 0036 watt.

3. Value omega ( $\mathrm{rad} / \mathrm{s})$, the largest in the arc angle of 300 , with a thickness of $1 \mathrm{~mm}, 2 \mathrm{~mm}, 3 \mathrm{~mm}$. The greatest value at the angle of 300 , with a thickness of $3 \mathrm{~mm}$, number of revolutions produced 5 times with a time of 5:33 s, omega values obtained $0938 \mathrm{rad} / \mathrm{s}$.

4. Off-shore testing with the ballasts $12 \mathrm{~cm}$ on the arc angle of 300 , the largest power produced at a thickness of $3 \mathrm{~mm}$ at an angle of 600 , the generated power 0037 watt.

5. Off-shore testing with the ballasts $12 \mathrm{~cm}$, the value of omega $(\mathrm{rad} / \mathrm{s})$, the largest in the arc angle of 300, with a thickness of $1 \mathrm{~mm}, 2 \mathrm{~mm}, 3 \mathrm{~mm}$. The greatest value at the angle of 600 , with a thickness of $3 \mathrm{~mm}$, number of revolutions produced seven times at 9:53 $\mathrm{s}$, omega values obtained $0735 \mathrm{rad} / \mathrm{s}$.

6. Off-shore testing with the ballasts $15 \mathrm{~cm}$ on the arc angle of 300 , the largest power produced at a thickness of $3 \mathrm{~mm}$ at an angle of 600 , the generated power 0041 watt.

7. Off-shore testing with the ballasts $15 \mathrm{~cm}$, the value of omega ( $\mathrm{rad} / \mathrm{s})$, the largest in the arc angle of 300 , with a thickness of $1 \mathrm{~mm}, 2 \mathrm{~mm}, 3 \mathrm{~mm}$. The greatest value at the angle of 450 , with a thickness of $2 \mathrm{~mm}$, the number of revolutions produced six times with a time of 7:08 s, omega values obtained $0847 \mathrm{rad} / \mathrm{s}$.

8. Testing Off- shore with ballasts $17.5 \mathrm{~cm}$ on the arc angle of 300 , the largest power produced at a thickness of $3 \mathrm{~mm}$ at an angle of 600 , the generated power 0032 watt.

9. Testing Off- shore with ballasts $17.5 \mathrm{~cm}$, the value of omega $(\mathrm{rad} / \mathrm{s})$, the largest in the arc angle of 300 , with a thickness of $1 \mathrm{~mm}, 2 \mathrm{~mm}, 3 \mathrm{~mm}$. The greatest value at the angle of 300 , with a thickness of $2 \mathrm{~mm}$, the number of revolutions produced three times with a time of 3:54 s, omega values obtained $0847 \mathrm{rad} / \mathrm{s}$.

\section{REFERENCES}

[1]. DESIGN OF OCEAN SYSTEMS. 2001. MIT, Massachutes Institute Of Technology.

[2]. Zamrisyaf. 2010. Penemu Listrik Tenaga Gelombang Laut Sistem Bandulan.

[3]. International Energy Agency- Ocean Energy System (IEA|OES) Ref: Policy Report. Tahun 2006

[4]. Wardhana, Ede Mehta. 2013. Analisa tegangan dan penempatan mooring pada pontoon pembangkit listrik tenaga laut sistem bandulan, Skripsi, Dept. Of Marine Engineering, ITS, Surabaya.

[5]. Babarit A, Clement AH, Gilloteaux JC Optimization and timedomain simulation of the SEAREV wave energy converter. In : Proceedings of $24^{\text {th }}$ International Conference Offshore Mechanics Arctic Engineering, Halkidiki, Greece; 2005, vol. 2, p. 703-12.

[6]. Munawaroh, Raudhotul. 2013. Kajian eksperimen gerakan pendulum pada pembangkit listrik tenaga gelombang laut- sistem bandula pada kondisi uji on-shore dan off-shore, Skipsi, Dept. Of Marine Engineering ITS, Surabaya.

[7]. Teori Bangunan Kapal. Stabilitas Suatu Kapal.

[8]. Wkibooks Indonesia, Pelayaran Sungai dan Danau / Dasar-Dasar Kapal.

[9]. Rudianto. 2010. Analisa gerakan pendulum dengan bentuk juring lingkaran pada pembangkit listrik tenaga gelombang lautsistem bandul pada pengujian offshore, skripsi, Dept. Of Marine Engineering ITS, Surabaya.

[10]. FISIKA 1 soal - soal seri C. 2012. Dosen -dosen Fisika Fakultas Matematika dan Ilmu Pengetahuan Alam, Institut Teknologi 
International Journal of Marine Engineering Innovation and Research, Vol. 1(2), Mar. 2017. 114-119 (pISSN: 2541-5972, eISSN: 2548-1479)

Sepuluh Nopember.

[11]. Bambang M, PGD., Tony. Personal konsultasi Lab Marine Manufacturing and Design, Sistem Perkapalan ITS, Surabaya, 16 Desember 2015.

[12]. Syarief A.ST, MT, Irfan. Personal konsultasi Lab Marine Manufacturing and Design, Sistem Perkapalan ITS, Surabaya, 9 Maret 2016. 